24 Kaplan EL, Meier P. Nonparametric estimation from incomplete observations. Foumal of the American Statistical Association 1958;53:457-81.

25 Cox DR. Regression models and life-tables. $7 R$ Stat Soc [B]1972:34:187-220.

26 Thomas DG, Bresow N, Gart JJ. Trend and hom proportions and life table data. Comput Biomed Res 1977;10:373-81.

27 Kleinbaum DG, Kupper LL, Muller KE. Applied regression analysis and other . Kods. Boston: PWS-Kent Publishing Company, 1988.

28 Medley GF, Billard L, Cox DR, Anderson RM. The distribution of the incubation period for the acquired immunodeficiency syndrome (AIDS). Proc R Soc Lond [B] 1988; 233:367-77.
29 Simmonds P, Lainson FA, Cuthbert R, Steel CM, Peutherer JF, Ludlam CA. HIV antigen and antibody detection: variable responses to infection in the Edinburgh haemophiliac cohort. BM7 1988;296:593-8.

30 Pizzo PA. Pediatric AIDS: problems within problems. F Infect Dis 1990;161 316-25.

31 Cuthbert RJG, Ludlam CA, Tucker J, Steel CM, Beatson D, Rebus S, et al. Five year prospective study of HIV infection in the Edinburgh haemophiliac
cohort. BMF 1990;301:956-61.

Accepted 4 November 1991)

3

\title{
Controlled low protein diets in chronic renal insufficiency:
} meta-analysis//

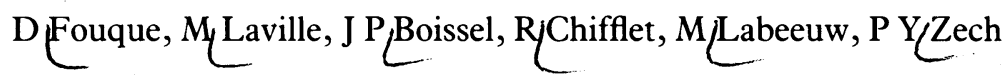

\section{Abstract}

Objective-To determine whether low protein diets retard the development of end stage renal disease.

Design-Meta-analysis of 46 trials since 1975, from which six randomised controlled trials were selected.

Setting - Five trials in Europe and one in Australia between 1982 and 1991.

Subjects -890 patients with mild to severe chronic renal failure who were followed up for at least one year. $\mathbf{4 5 0}$ patients received a low protein diet and $\mathbf{4 4 0}$ a control diet.

Intervention-Difference in protein intake between control and treated groups of at least $0.2 \mathrm{~g}$ protein $/ \mathrm{kg} / \mathrm{day}$.

Main outcome measure-Number of renal deaths (the necessity to start dialysis or death of patient during study).

Results - 156 renal deaths were recorded, 61 in the low protein diet group and 95 in the control group, leading to an odds ratio of low protein to control of 0.54 with a $95 \%$ confidence interval of 0.37 to 0.79 .

Conclusions-This result, obtained on a large population of patients suffering from chronic renal insufficiency, strongly supports the effectiveness of low protein diets in delaying the onset of end stage renal disease.

\section{Introduction}

During the past 10 years a lot of experimental data have suggested that dietary protein restriction may retard or even halt the development of non-specific glomerular lesions and hence the progression of end stage renal disease. Despite the many studies on dietary

Service de Néphrologie, Hôpital Edouard Herriot, 69437 Lyon)Cedex 03 $\mathrm{D}$ Pouque, $\mathrm{MD}$, head of clinic M Laville, MD, professor of therapeutics

$M$ Labeeuw, MD, professor of nephrology

$\mathrm{P}$ Zech, MD, professor of

nephrology

\section{Laboratoire de}

Pharmacologie Clinique, 162 Avenue Lacassagne, 69424 Lyon

J P Boissel, MD, professor of clinical pharmacology

R Chifflet, PHD, statistician

Correspondence to:

Dr Fouque.

BMf 1992;304:216-20 data to determine the number of patients reaching stage renal disease during follow up. This metaanalysis, should enable the strength of the association between low protein diet and reduction in end stage renal failure to be assessed, taking into consideration the bias due to the various confounding factors (such as regression to the mean) and avoiding the use of intermediate criteria (such as the slope of the time course for the reciprocal values of serum creatinine concentration and the rate of decay of creatinine clearance).

\section{Methods}

The principle of meta-analysis entails the adjusted analysis of results in a collection of studies, with a unique criterion for all studies. Meta-analysis is particularly suitable for studies of rare events in, for example, ponderous or longlasting trials that do not include many patients. ${ }^{7-9}$ The quality and impact of a meta-analysis depends on the selection process for the criterion, which must be well defined at the beginning of the meta-analysis, and easily collected by nonspecialist observers.

Definition of a common event - We defined renal death as either the necessity to begin dialysis or the death of patients during the study. Patients receiving grafts before starting dialysis were counted as having had renal death. Patients who were lost to follow up or who stopped taking the diet were not counted as having had renal death. These criteria were applied independently of the randomised treatment by the authors on the basis of published data or complementary data kindly provided by the investigators.

Collection of data and study selection-To avoid omission of results from less well known studies we scanned research reports with a computer search of Medline files and abstract books from the International Society of Nephrology and the American Society of Nephrology. We also asked many investigators for complete or incomplete, published or unpublished randomised studies. We restricted the review to randomised trials because without randomisation lack of bias cannot be guaranteed. Trials that used other methods of allocating treatments (such as retrospective controls and non-randomised, crossover, or prospective uncontrolled protocols) were therefore not included. Trials studying only diabetic nephropathy were not selected, because the equilibrium of diabetes is of major importance in the progression of renal failure and cannot be adequately measured between control and treated groups. Table I summarises 46 studies on protein restriction and its effects on the progression of chronic renal insufficiency. Individual data and extra details if not mentioned in the original papers, were collected from investigators who kindly agreed to send us their raw data.

Statistical methods-Intention to treat analysis was made on the selected populations, randomly assigned to control or treated groups (a restricted protein diet). Standard statistical methods were used (percentage 
TABLE I - Summary of different trials studying the impact of protein restriction on renal function since 1975 and reasons for exclusion from analysis

\begin{tabular}{|c|c|c|c|}
\hline $\begin{array}{l}\text { First author and } \\
\text { reference No }\end{array}$ & Year & Reason for exclusion & $\begin{array}{c}\text { No of } \\
\text { patients }\end{array}$ \\
\hline Walser" & 1975 & Prospective non-controlled & 7 \\
\hline Burns': & 1978 & Prospective non-controlled & 7 \\
\hline Alvestrand $d^{\prime}$ & 1980 & Retrospective & 68 \\
\hline Frohling ${ }^{+}$ & 1980 & Prospective controlled & 26 \\
\hline Hecking" & 1980 & $\begin{array}{l}\text { Prospective, double blind } \\
\text { crossover, six week study }\end{array}$ & 15 \\
\hline $\mathrm{Kampf}^{\mathrm{th}}$ & 1980 & Prospective non-controlled & 20 \\
\hline Barsotti ${ }^{7}$ & 1981 & Retrospective & 56 \\
\hline Maschio $^{18}$ & 1982 & Prospective controlled & 75 \\
\hline Alvestrand ${ }^{19}$ & 1983 & Retrospective & 17 \\
\hline Attman ${ }^{2 \omega}$ & 1983 & Prospective non-controlled & 21 \\
\hline Barsotti ${ }^{24}$ & 1983 & Same patients as Barsotti & \\
\hline Bennett $^{22}$ & 1983 & Retrospective & 96 \\
\hline Frohling ${ }^{23}$ & 1983 & Prospective non-controlled & 46 \\
\hline Gretz $^{2+}$ & 1983 & Prospective controlled & 161 \\
\hline Barsotti ${ }^{15}$ & 1984 & Prospective controlled & 55 \\
\hline El Nahas ${ }^{\text {: }}$ & 1984 & Prospective non-controlled & 34 \\
\hline Mitch & 1984 & Prospective non-controlled & 24 \\
\hline $\operatorname{Rosman}^{2 x}$ & 1984 & $-t$ & 228 \\
\hline Gretz $z^{\prime \prime \prime}$ & 1985 & Same patients as Gretz $z^{24}$ & \\
\hline Oldrizzi" $^{\text {ti }}$ & 1985 & Prospective controlled & 100 \\
\hline Rosman" & 1985 & Same patients as Rosman & \\
\hline Williams $^{12}$ & 1985 & Same patients as Bennett": & \\
\hline Zakar $^{33}$ & 1985 & Prospective controlled & 60 \\
\hline Attman & 1986 & Retrospective & 119 \\
\hline Chauveau & 1986 & Same patients as Jungers ${ }^{43}$ & \\
\hline Di Landro ${ }^{\text {in }}$ & 1986 & Prospective controlled & 68 \\
\hline Gentile & 1986 & Same patients as Locatelli ${ }^{\text {s+ }}$ & \\
\hline Gretz $^{i k}$ & 1986 & Same patients as Gretz $z^{24}$ & \\
\hline $\operatorname{Lucas}^{39}$ & 1986 & Prospective non-controlled & 12 \\
\hline Rosman & 1986 & Same patients as Rosman ${ }^{28}$ & \\
\hline Schmicker ${ }^{+1}$ & 1986 & Prospective controlled & 119 \\
\hline Gretz $z^{4}$ & 1987 & Same patients as Gretz ${ }^{24}$ & \\
\hline Jungers $^{47}$ & 1987 & $-t$ & 19 \\
\hline Meisinger & 1987 & Prospective controlled. & 38 \\
\hline Schmicker" & 1987 & Same patients as Schmicker" & \\
\hline Walser ${ }^{\text {to }}$ & 1987 & Prospective non-controlled & 12 \\
\hline Williams $^{4}$ ? & 1987 & $-t$ & 65 \\
\hline Barsottits & 1988 & Prospective non-controlled & 8 \\
\hline Gentile $^{14}$ & 1988 & Same patients as Locatelli $\mathrm{s}^{4}$ & \\
\hline Bagros $^{\star}$ & 1989 & $-\dagger$ & 50 \\
\hline Frohling ${ }^{50}$ & 1989 & Prospective controlled & 81 \\
\hline Gretz $^{4}$ & 1989 & Same patients as Gretz $z^{24}$ & \\
\hline Ihles & 1989 & $-t$ & 72 \\
\hline Levine & 1989 & Prospective non-controlled & 7 \\
\hline Locatelli ${ }^{4}$ & 1991 & $-t$ & 456 \\
\hline Zeller"s & 1991 & Diabetic patients only & 35 \\
\hline
\end{tabular}

TABLE II -Summary of data from six randomised controlled studies selected for meta-analysis

\begin{tabular}{|c|c|c|c|c|c|c|c|c|c|}
\hline $\begin{array}{l}\text { Study } \\
\text { No }\end{array}$ & $\begin{array}{l}\text { Place, } \\
\text { reference No }\end{array}$ & $\begin{array}{c}\text { Year of } \\
\text { publication }\end{array}$ & $\begin{array}{c}\text { No of } \\
\text { patients }\end{array}$ & $\begin{array}{c}\text { Mean age } \\
\text { (years) } \\
\text { (range) }\end{array}$ & $\begin{array}{c}\text { Follow up } \\
\text { (months) }\end{array}$ & $\begin{array}{l}\text { No with } \\
\text { dialysis }\end{array}$ & $\begin{array}{c}\text { No of } \\
\text { deaths }\end{array}$ & $\begin{array}{l}\text { No of } \\
\text { grafts }\end{array}$ & $\begin{array}{c}\text { No of } \\
\text { renal } \\
\text { deaths }\end{array}$ \\
\hline 1 & $\begin{array}{l}\text { Groningen, } \\
\text { Rosman }\end{array}$ & 1984 & 228 & $48(15-73)$ & 18 & 14 & 6 & 3 & 23 \\
\hline 2 & Paris, Jungers ${ }^{43}$ & 1987 & 19 & $62(32-79)$ & 12 & 12 & 0 & 0 & 12 \\
\hline \multirow[t]{2}{*}{3} & Northern Italy, & & & & & & & & \\
\hline & $\begin{array}{l}\text { Locatelli } \\
\text { Tours, Bagros }\end{array}$ & $\begin{array}{c}1991 \\
\text { Unpublished }\end{array}$ & $\begin{array}{r}456 \\
50\end{array}$ & $\begin{array}{l}49(18-65) \\
55(15-75)\end{array}$ & $\begin{array}{l}24 \\
18\end{array}$ & $\begin{array}{l}47 \\
25\end{array}$ & $\begin{array}{l}6 \\
3\end{array}$ & $\begin{array}{l}0 \\
0\end{array}$ & $\begin{array}{l}53 \\
28\end{array}$ \\
\hline \multirow{3}{*}{$\begin{array}{l}4 \\
5 \\
6\end{array}$} & Victoria, Ihles: & 1989 & 72 & - & 18 & 17 & 0 & 0 & 17 \\
\hline & Liverpool, & & & & & & & & 23 \\
\hline & W & 1987 & 65 & $44(15-70)$ & 18 & 22 & 1 & 0 & 23 \\
\hline All & & 890 & & & & 137 & 16 & 3 & 156 \\
\hline
\end{tabular}

TABLE III -Details of populations and renal deaths in control and treated groups of each trial and summary of results

\begin{tabular}{|c|c|c|c|c|c|c|c|c|}
\hline \multirow[b]{2}{*}{$\begin{array}{l}\text { Study } \\
\text { No }\end{array}$} & \multirow[b]{2}{*}{ Diet } & \multirow[b]{2}{*}{$\begin{array}{l}\text { No of } \\
\text { patients }\end{array}$} & \multirow[b]{2}{*}{$\begin{array}{c}\text { Sex ratio } \\
(M / F)\end{array}$} & \multicolumn{5}{|c|}{ No of patients with: } \\
\hline & & & & $\begin{array}{l}\text { Glomerulo- } \\
\text { nephritis }\end{array}$ & $\begin{array}{l}\text { Polycystic } \\
\text { disease }\end{array}$ & $\begin{array}{c}\text { Interstitial } \\
\text { nephritis }\end{array}$ & $\begin{array}{c}\text { Other } \\
\text { nephropathies }\end{array}$ & $\begin{array}{l}\text { Renal } \\
\text { death }\end{array}$ \\
\hline 1 & $\left\{\begin{array}{l}\text { Control } \\
\text { Treated }\end{array}\right.$ & $\begin{array}{l}110 \\
118\end{array}$ & $\begin{array}{l}62 / 48 \\
62 / 56\end{array}$ & $\begin{array}{l}36 \\
43\end{array}$ & $\begin{array}{r}4 \\
10\end{array}$ & $\begin{array}{l}31 \\
23\end{array}$ & $\begin{array}{l}39 \\
42\end{array}$ & $\begin{array}{r}15 \\
8\end{array}$ \\
\hline 2 & $\left\{\begin{array}{l}\text { Control } \\
\text { Treated }\end{array}\right.$ & $\begin{array}{r}9 \\
10\end{array}$ & $\begin{array}{l}2 / 7 \\
5 / 5\end{array}$ & $\begin{array}{l}3 \\
2\end{array}$ & $\begin{array}{l}2 \\
2\end{array}$ & $\begin{array}{l}2 \\
1\end{array}$ & $\begin{array}{l}2 \\
5\end{array}$ & $\begin{array}{l}7 \\
5\end{array}$ \\
\hline 3 & $\left\{\begin{array}{l}\text { Control } \\
\text { Treated }\end{array}\right.$ & $\begin{array}{l}226 \\
230\end{array}$ & $\begin{array}{l}127 / 99 \\
120 / 110\end{array}$ & $\begin{array}{l}66 \\
66\end{array}$ & $\begin{array}{l}40 \\
34\end{array}$ & $\begin{array}{l}71 \\
85\end{array}$ & $\begin{array}{l}49 \\
45\end{array}$ & $\begin{array}{l}32 \\
21\end{array}$ \\
\hline 4 & $\left\{\begin{array}{l}\text { Control } \\
\text { Treated }\end{array}\right.$ & $\begin{array}{l}25 \\
25\end{array}$ & $\begin{array}{l}15 / 10 \\
14 / 11\end{array}$ & $\begin{array}{l}6 \\
8\end{array}$ & $\begin{array}{l}9 \\
6\end{array}$ & $\begin{array}{l}3 \\
4\end{array}$ & $\begin{array}{l}7 \\
7\end{array}$ & $\begin{array}{l}17 \\
11\end{array}$ \\
\hline 5 & $\left\{\begin{array}{l}\text { Control } \\
\text { Treated }\end{array}\right.$ & $\begin{array}{l}38 \\
34\end{array}$ & $\begin{array}{l}24 / 14 \\
24 / 10\end{array}$ & $\begin{array}{l}17 \\
17\end{array}$ & $\begin{array}{l}7 \\
6\end{array}$ & $\begin{array}{r}10 \\
9\end{array}$ & $\begin{array}{l}4 \\
2\end{array}$ & $\begin{array}{r}13 \\
4\end{array}$ \\
\hline 6 & $\left\{\begin{array}{l}\text { Control } \\
\text { Treated }\end{array}\right.$ & $\begin{array}{l}32 \\
33\end{array}$ & $\begin{array}{l}21 / 11 \\
20 / 13\end{array}$ & $\begin{array}{l}8 \\
7\end{array}$ & $\begin{array}{l}6 \\
5\end{array}$ & $\begin{array}{l}5 \\
6 \\
\end{array}$ & $\begin{array}{l}13 \\
15\end{array}$ & $\begin{array}{l}11 \\
12\end{array}$ \\
\hline All & $\left\{\begin{array}{l}\text { Control } \\
\text { Treated }\end{array}\right.$ & $\begin{array}{l}440 \\
450\end{array}$ & $\begin{array}{l}251 / 189 \\
245 / 205\end{array}$ & $\begin{array}{l}136 \\
143\end{array}$ & $\begin{array}{l}68 \\
63\end{array}$ & $\begin{array}{l}122 \\
128\end{array}$ & $\begin{array}{l}114 \\
116\end{array}$ & $\begin{array}{l}95 \\
61\end{array}$ \\
\hline
\end{tabular}

differences; logarithm of odds ratio; Cochran; MantelHaenszel; Peto). ${ }^{78}$ As they all gave similar $p$ values for the difference between control and treated groups, only the results from the analysis of the logarithm of odds ratio are given. These results represent the ratios of the number of events in the treated group times the number of non-events in the control group to the number of events in the control group times the number of non-events in the treated group. For simplification it is useful to consider the odds ratio and its $95 \%$ confidence interval. An odds ratio of 0.60 corresponds to a reduction of $40 \%$ in the odds of experiencing an event. Heterogeneity between trialsthat is, the interaction between trials and the effect of treatment-was tested by the appropriate $\chi^{2}$ test. $^{10}$ However, such tests of heterogeneity between many different trials have a limited value, partly because they are dominated by unstable contributions from the smaller studies that could obscure any real heterogeneity between the larger studies and, partly because of a low power.

\section{Results}

\section{STUDY POPULATION}

From 46 trials between 1975 and 1991 (table I), only six reports of randomised controlled trials were selected. Four were reported as full length articles (studies 1, 2, 3, and 5), one was presented as an oral communication and is not yet published (study 4, Bagros et al, personal communication), and the sixth was published as an abstract (study 6). Randomisation was from one centre in all six studies and by allocating an envelope after stratification by age, sex, and renal function in study 1 , by allocating an envelope in studies 2,5 , and 6 , by random number table and a telephone call in study 3 , and by random number table in study 4 .

\section{DESCRIPTION OF PATIENTS STUDIED}

The data on the patients studied are summarised in tables II and III. Patients varied between trials in age, sex ratio, and population size. The length of follow up was homogeneous, between 12 and 24 months. In study 1 not all the randomised patients were followed up for 18 months, but we considered the initial randomised population for intention to treat analysis. In study 5 we considered the initial 72 randomised patients and not the final 64 patients in the published results. In study 6 we considered two of the three randomised groups (control, low protein diet, and low phosphorus diet), rejecting the low phosphorus group because lowering phosphorus intake alone was not suitable for our analysis. The level of renal insufficiency was heterogeneous (table IV), from mild (study 3 ) to severe (study 2). The follow up criteria for renal function were also heterogeneous, with the use of serum creatinine concentration in studies 1,2 , and 6 ; renal survival (end point defined as the need for dialysis or the doubling of the plasma creatinine concentration) in study 3; estimation of glomerular filtration rate ((creatinine clearance + urea clearance)/2) according to Lubowitz et $a l^{56}$ in study 4 ; and the clearance of ethylenediaminetetra-acetic acid labelled with chromium- 51 in study 5 .

The incidence of renal death in control groups was variable $(0.14$ in study 1 to 0.78 in study 2$)$, which may be a result of renal insufficiency at inclusion. However, the heterogeneity test for the control groups was not significant.

\section{TREATMENTS}

A large heterogeneity was observed for the reduced protein intakes. It should be noted that the intake of protein in the control group in study 2 was about the 
TABLE IV - Follow up, renal function at inclusion, and diets in six studies selected for meta-analysis

\begin{tabular}{|c|c|c|c|c|}
\hline \multirow{2}{*}{$\begin{array}{l}\text { Study } \\
\text { No }\end{array}$} & \multirow{2}{*}{$\begin{array}{l}\text { Follow up criterion of } \\
\text { renal function }\end{array}$} & \multirow[b]{2}{*}{ Renal function at inclusion } & \multicolumn{2}{|c|}{ Diet } \\
\hline & & & Treated group & Control group \\
\hline 1 & $\begin{array}{l}\text { Reciprocal of serum creatinine } \\
\text { (all groups) }\end{array}$ & $\begin{array}{l}\text { Creatinine clearance } \\
(\mathrm{A} 2, \mathrm{C} \leq 30 \text { and }>10 \mathrm{ml} / \mathrm{min} \\
\mathrm{A} 1, \mathrm{~B} \leq 60 \text { and }>30 \mathrm{ml} / \mathrm{min})\end{array}$ & $\begin{array}{l}\text { B } 0.6 \mathrm{~g} \text { Protein } / \mathrm{kg} \text { body weight } / \text { day } \\
\text { C } 0.4 \mathrm{~g} \text { Protein } / \mathrm{kg} \text { body weight } / \text { day }\end{array}$ & Free $\operatorname{diet}(\mathrm{A} 1, \mathrm{~A} 2)$ \\
\hline 2 & Increase in serum creatinine & $\begin{array}{l}\text { Serum creatinine between } 500 \\
\text { and } 900 \mu \mathrm{mol} / 1\end{array}$ & $\begin{array}{l}0.4 \mathrm{~g} \text { Protein } / \mathrm{kg} \text { body weight } / \text { day } \\
\text { with ketoacids supplementation } \\
\text { Ketosteril } 1 \text { tablet } / 6 \mathrm{~kg} / \mathrm{day}\end{array}$ & $0.6 \mathrm{~g}$ Protein $/ \mathrm{kg}$ body weight/day \\
\hline 3 & $\begin{array}{l}\text { Renal survival curve (doubling } \\
\text { of serum creatinine at inclusion } \\
\text { or need for dialysis) }\end{array}$ & $\begin{array}{l}\text { Serum creatinine between } 130 \\
\text { and } 620 \mu \mathrm{mol} / 1\end{array}$ & $0.6 \mathrm{~g}$ Protein $/ \mathrm{kg}$ body weight $/$ day & $1 \mathrm{~g}$ Protein $/ \mathrm{kg}$ body weight $/$ day \\
\hline 4 & $\begin{array}{l}\text { Estimated glomerular filtration } \\
((\text { creatinine clearance + urea } \\
\text { clearance }) / 2)\end{array}$ & $\begin{array}{l}\text { Serum creatinine between } 300 \\
\text { and } 900 \mu \mathrm{mol} / 1\end{array}$ & $\begin{array}{l}0.3 \mathrm{~g} \text { Protein } / \mathrm{kg} \text { body weight } / \text { day } \\
\text { with ketoacids supplementation } \\
\text { (Ketosteril } 1 \text { tablet } 6 \mathrm{~kg} / \text { day) }\end{array}$ & $0.65 \mathrm{~g}$ Protein $/ \mathrm{kg}$ body weight $/$ day \\
\hline 5 & Plasma clearance of ${ }^{5} \mathrm{Cr}$-EDTA & $\begin{array}{l}\text { Serum creatinine between } 350 \\
\text { and } 1000 \mu \mathrm{mol} / 1\end{array}$ & $0.4 \mathrm{~g}$ Protein $/ \mathrm{kg}$ body weight/day & $\begin{array}{l}\text { Free diet }>0.75 \mathrm{~g} \text { protein } / \mathrm{kg} \text { body } \\
\text { weight } / \text { day }\end{array}$ \\
\hline 6 & Reciprocal of serum creatinine & $\begin{array}{l}\text { Serum creatinine between } 200 \\
\text { and } 600 \mu \mathrm{mol} / 1\end{array}$ & $0.6 \mathrm{~g}$ Protein $/ \mathrm{kg}$ body weight/day & $>0.8 \mathrm{~g}$ Protein $/ \mathrm{kg}$ body weight $/$ day \\
\hline
\end{tabular}

"Cr-EDTA = ethylenediaminetetra-acetic acid labelled with chromium-51.

same as the degree of protein restriction in the treated group in study 3 (table IV). However, the mean difference in protein intake between control and treated groups was at least $0.35 \mathrm{~g} / \mathrm{kg} / \mathrm{day}$ in all studies except studies 2 and 6 , when it was $0 \cdot 2 \mathrm{~g} / \mathrm{kg} / \mathrm{day}$. Interestingly, the treated groups in studies 2 and 4, which had the strictest restrictions received a ketoacid supplement.

\section{HOMOGENEITY OF STUDIES}

There was no qualitative interaction between effect and treatment. The $\chi^{2}$ heterogeneity test between odds ratios was $4 \cdot 05$, with five degrees of freedom $(p=0.54)$. Thus, the hypothesis that the effect of treatment in the different trials is heterogeneous is rejected.

\section{EFFECTS OF DIETARY INTERVENTION ON INCIDENCE OF} RENAL DEATH

Renal deaths are noted in tables II and III and the

TABLE V-Odds of renal death in six prospective randomised studies of protein restriction in studies of protein restriction
chronic renal insufficiency

\begin{tabular}{lcc}
\hline & $\begin{array}{c}\text { Odds ratio } \\
\text { (treatment/ } \\
\text { control) }\end{array}$ & $\begin{array}{c}95 \% \\
\text { Confidence } \\
\text { interval }\end{array}$ \\
\hline 1 & 0.46 & 0.19 to 1.13 \\
2 & 0.29 & 0.04 to 2.11 \\
3 & 0.61 & 0.34 to 1.09 \\
4 & 0.37 & 0.12 to 1.17 \\
5 & 0.28 & 0.08 to 0.95 \\
6 & 1.09 & 0.40 to 3.02 \\
\hline All & 0.54 & 0.37 to 0.79 \\
\hline
\end{tabular}

$\chi^{2}=4.05, \mathrm{df}=5, \mathrm{p}=0.54$ for test of heterogeneity between odds ratios. statistical results are shown in table $\mathrm{V}$. In the six studies the number of renal deaths observed in treated and control groups were respectively 8 and 15 in study 1,5 and 7 in study 2, 21 and 32 in study 3,11 and 17 in study 4,4 and 13 in study 5 , and 12 and 11 in study 6 . Five trials showed a reduction in renal death in treated groups and one a slight increase in renal death in the treated group (study 6). Only the results for study 5 were significant as the confidence interval of the odds ratio did not include 1 . After summarising the data 156 renal deaths were recorded, 61 for the treated groups (450 patients) and 95 for the control groups (440 patients). This represents a highly significant reduction in renal death (odds ratio $0.54,95 \%$ confidence interval 0.37 to $0.79 ; p<0.002$ ) for subjects allocated to low protein diets.

\section{Discussion}

One of the problems in measuring the progression of renal insufficiency is the identification of aetiological or therapeutic factors that may improve renal function. ${ }^{67}$ Inadequate markers or protocols or confounding factors may mask the effects of low protein diets. ${ }^{67} \mathrm{Of}$ the 46 trials analysed, only three used reference methods to measure glomerular filtration rate - that is 119 out of 2277 patients $(5 \cdot 2 \%){ }^{465255}$ To avoid problems raised by surrogate criteria we chose a clearly defined clinical end point, renal death. This end point was easily observed for all patients retrospectively that is, the date of the first dialysis session. These data were obtained accurately from each paper or by direct contact with the investigators.

In this review low protein diets were shown to reduce renal deaths significantly in the treated groups. The reduction of renal deaths occurred in five of the six trials (table $\mathrm{V}$ ). In practical terms this reduction represents a longer period before the start of dialysis, but it should not be taken to represent a reduction in the progression of renal disease.

This review has four potential limitations. Firstly, although the populations studied are clinically heterogeneous in age, sex ratio, level of renal insufficiency, and protein restriction, as seen in tables II, III, and IV, the effects of treatment are not statistically different. This heterogeneity of patients and degree of renal function is due, in part, to the small number of subjects. Interestingly, as observed for patients entering dialysis, ${ }^{58}$ more male subjects were present in these trials (sex ratio $(\mathrm{m} / \mathrm{f}) 1 \cdot 26)$ and were identically distributed in both control and treated groups (table III). The different kinds of nephropathies were also equally distributed to avoid clustering of glomerulonephritides which are more sensitive to low protein diets. ${ }^{40}$ The limited number of patients presenting with stabilised renal insufficiency associated with the difficulty of dietary follow up may explain the individual trial sizes and the low significance of results. ${ }^{4}$ However, this heterogeneity may be viewed as an advantage for metaanalysis, because if it gives positive results it thus indicates a broader applicability of the treatment. ${ }^{?}$

Secondly, as the decision to begin dialysis varies locally, the definition of our criterion depends on physicians' opinions, the dialysis unit, and sometimes financial restrictions. The five countries involved (the Netherlands, France, Italy, Australia, and England) do not have dialysis restrictions and may start at similar degrees of renal insufficiency. Nevertheless, dialysis should be started at the same time for each trial in both treated and control groups according to clinical symptoms.

Thirdly, although the protein intake in the treatment and control diets varies, the fact that a common effect is found indicates that the gradient in protein content is the therapeutic factor. In fact, the widely observed drift during low protein diets is due to a regular increase in the protein intake with time for treated groups ${ }^{59}$ and an underestimation of protein intake by the dietary reports..$^{60}$ These two facts tend to minimise the real gradient of protein intake between control and treated groups. Despite this, our metaanalysis is significant, and any factor that would minimise the difference in protein intake between control and treated groups-poor observance of protein restriction in the treated group or spontaneous restriction in the control group-would in fact enhance the significance of the meta-analysis. Thus, one reason why the individual studies gave weakly significant results could be that there was a too small protein gradient between treated and control groups at the start or during the trial (studies 2 and 6). The only significant study (study 5) showed a mean difference in protein intake of $13 \mathrm{~g} /$ day at six months (estimated by 
urea nitrogen excretion; Maroni, et al's correction is not useful in estimating a gradient of protein intake) in 50 patients. ${ }^{61}$ For a mean estimated weight of $60 \mathrm{~kg}$ (two thirds male patients, one third female) this represents a difference of $0.25 \mathrm{~g} / \mathrm{kg} /$ day of protein. The significance of this meta-analysis could decrease if the treated groups ate less protein than prescribed and the control groups more. This would probably improve the effects of true protein restriction on renal function.

Fourthly, in the control groups (less or unrestricted protein intake) increased urea production may decrease clinical tolerance and hasten the decision to start dialysis, compared with the treated groups. This potential limitation has not been resolved, so clinical intolerance of urea is only one of many reasons for starting dialysis.

\section{CONCLUSION}

Finally, the heterogeneity does not limit the results from this meta-analysis. From this review low protein diets have clearly been found to delay end stage renal disease. However, no conclusion may be drawn about its effects on the rate of progression of renal insufficiency or on its nutritional risks or additional benefits on osteodystrophy, anaemia, and quality of life. Level of restriction and need for supplements could also not be measured. This meta-analysis should not be considered as definitive as renal death was not the end point used in the six studies. A new randomised controlled trial should be initiated with a sufficient number of patients. From the mean reduction of risk observed in our meta-analysis, it can be estimated that this trial should include at least 800 patients (control risk of event $=0.21$, odds ratio $=0.54$, two sided hypothesis, $\alpha=0.05, \beta=0.05$ ). Renal death should be closely monitored, as well as all other reasons for leaving the study. The modification of diet in renal disease study is suitable for this type of approach. ${ }^{5760}$

1 El Nahas AM, Coles GA. Dietary treatment of chronic renal failure: ten unanswered questions. Lancet 1986;i:597-600.

2 Druml W, Mitch WE. Protein-restricted diets and progression of renal failure Blood Purif 1988;6:285-98.

3 Giovannetti S. Answers to ten questions on the dietary treatment of chronic renal failure, on behalf of the Steering Committee of the European Study Groups for the Conservative Treatment of Chronic Renal Failure. Lancet 1986;ii:1140-2.

4 Gretz N, Giovannetti S, Barsotti G, Schmicker R, Rosman J. Influence of dietary treatment on the rate of progression of chronic renal failure. In dietary treatment on the rate of progression of chronic renal failure. In:
Giovannetti $S$, ed. Nutritional treatment of chronic renal failure. Boston, Giovannetti S, ed. Nutritional treatmen

5 Walser M. Progression of chronic renal failure in man. Kidney Int 1990;37: 1195-210.
. Palser M. Prog

6 Levey A. Nephrology forum: measuring renal function. Kidney Int 1990;38: $167-84$.

7 Boissel JP, Blanchard J, Panak E, Peyrieux JC, Sacks H. Considerations fo the meta-analysis of randomized clinical trials, summary of a panel discussion. Controlled Clin Trials 1989;10:254-81.

8 L'Abbe KA, Detsky AS, O'Rourke E. Meta-analysis in clinical research. Ann Intern Med 1987;107:224-33.

9 Sacks HS, Berrier J, Reitman D, Ancona-Berk VA, Chalmers TC. Metaanalyses of randomized controlled trials. $N$ Engl $\mathcal{F}$ Med 1987;316:450-5.

10 Hedges LV, Olkin I. Statistical methods for meta-analysis. Orlando, Florida Academic Press, 1985.

11 Walser M. Ketoacids in the treatment of uremia. Clin Nephrol 1975;3:180-6.

12 Burns J, Cresswell E, Ell S, Fynn M, Jackson MA, Lee HA, et al. Comparison of the effects of ketoacids analogues and essential aminoacids on nitrogen homeostasis in uremic patients on moderately protein-restricted diets. homeostasis in uremic patients

13 Alvestrand $A$, Ahlberg $M$, Fürst $P$, Bergstrom J. Clinical experience with amino acid and keto acid diets. Am F Clin Nutr 1980;33:1654-9.

14 Frohling PT, Schmicker R, Vetter K, Kaschube I, Gotz KH, Jacopian M, et al. Conservative treatment with ketoacid and aminoacid supplemented low-protein diets in chronic renal failure. Am f Clin Nutr 1980;33:1667-72.

15 Hecking E, Andrzejewski LI, Prellnitz W, Opferkuch W, Muller D. Double blind cross over study with oral and ketoacids in patients with chronic rena failure. Am f Clin Nutr 1980;33:1678-81.

$16 \mathrm{Kampf}$ D, Fischer HC, Kessel M. Efficacy of an unselected protein diet $(25 \mathrm{~g})$ with minor oral supply of essential amino acids and ketoanalogues compared with a selective protein diet $(40 \mathrm{~g})$ in chronic renal failure. Am 7 Clin Nutr 1980;33:1673-7.

17 Barsotti G, Guiducci A, Ciardella F, Giovanetti S. Effects on renal function of a low nitrogen diet supplemented with essential amino acids and ketoanalogues and of hemodialysis and free protein supply in patients with chronic renal failure. Nephron 1981:27:113-70.

18 Maschio G, Oldrizzi L, Tessitore N, D'Angelo A, Valvo E, Lupo A, et al. Effects of dietary protein and phosphorus restriction on the progression of early renal failure. Kidney Int 1982;22:371-6.

19 Alvestrand A, Ahlberg M, Bergstrom J. Retardation of the progression of renal insufficiency in patients treated with low-protein diets. Kidney Int Suppl 1983; 16:268-72

20 Attman PO, Bucht H, Larsson O, Uddebom G. Protein-reduced diet in diabetic renal failure. Clin Nephrol 1983;19:217-20.

21 Barsotti G, Morelli E, Giannoni A, Guiducci A, Lupetti S, Giovannetti S. Restricted phosphorus and nitrogen intake to slow the progression of chronic renal failure: a controlled trial. Kidney Int Suppl 1983;16:278-84.

22 Bennett SE, Russell GI, Walls J. Low protein diets in uraemia. BMJ $1983 ; 287: 1344-5$

23 Frohling PT, Kokot F, Smicker R, Kaschube I, Lindenau K, Vetter K. Influence of ketoacids on serum parathyroid hormone levels in patients with chronic renal failure. Clin Nephrol 1983;20:212-5.

24 Gretz N, Korb E, Strauch M. Low-protein diet supplemented by keto acids in chronic renal failure, a prospective controlled study. Kidney Int Suppl 1983:16:263-7.

25 Barsotti G, Giannoni A, Morelli E, Lazzeri M, Vlamis I, Baldi R, et al. The decline of renal function slowed by very low phosphorus intake in chronic renal patients following a low nitrogen diet. Clin Nephrol 1984:21:54-9.

26 El Nahas AM, Masters-Thomas A, Brady SA, Farrington K, Wilkinson V, Hilson AJ, et al. Selective effect of low protein diets in chronic renal diseases. BMf 1984;289:1337-41.

27 Mitch WE, Walser M, Steinman TI, Hill S, Zeger S, Tungsanga K. The effect of a keto acid-amino acid supplement to a restricted diet on the progression of chronic renal failure. $N$ Engl f Med 1984;6:623-9.

28 Rosman JB, Ter Wee PM, Meijer S, Piers-Becht TP, Sluiter WJ, Donker AJ. Prospective randomised trial of early dietary protein restriction in chronic renal failure. Lancet 1984;ii:1291-6.

29 Gretz N, Strauch M. Delayed progression of chronic renal failure: a prospective controlled trial with a low protein diet supplemented by keto acids. Contrib Nephrol 1985;49:78-86.

30 Oldrizzi L, Rugiu C, Valvo E, Lupo A, Loschiavo C, Gammaro L, et al. Progression of renal failure in patients with renal disease of diverse etiology Progression of renal failure in patients with renal dises
on protein-restricted diet. Kidney $\operatorname{lnt} 1985 ; 27: 553-7$.

31 Rosman JB, Ter Wee PM, Piers-Becht GP, Sluiter WJ, Meijer S, Van der Hem $\mathrm{GK}$, et al. Early protein restriction in chronic renal failure. In: Davison AM, GK, et al. Early protein restriction in chronic renal failure. In: Davison AM,
Guillou PJ, ed. Proceedings of the European Dialysis and Transplant Association-European Renal Association, 1984, Florence, Italy. London: Pitman, 1985:567-73.

32 Williams AJ, Bennett SE, Russell GI, Walls J. Alteration of the course of chronic renal failure by dietary protein restriction. In: Davison AM, Guillou PJ, ed. Proceedings of the European Dialysis and Transplant AssociationEuropean Renal Association, 1984, Florence, Italy. London: Pitman, 1985:604-7.

33 Zakar G. Effects of dietary protein restriction on the course of early rena failure. In: Davison AM, Guillou PJ, ed. Proceedings of the European Dialysis and Transplant Association-European Renal Association, 1984, Florence, Italy. London: Pitman, 1984:600-3.
Lond

34 Attman PO. Long term treatment with low protein diet in uremia. Contrib Nephrol 1986;53:128-6.

35 Chauveau P, Lebkiri B, Ployard F, Ciancioni C, Man NK, Jungers P. Effet des cétoanalogues des acides aminés essentiels sur la progression de l'insuffisance
rénale chronique avancée, étude prospective contrôlée. Nephrologie 1986;7: rénale c. $137-42$.

36 Di Landro D, Perin N, Bertoli M, Gasparotto ML, Ruffatti A, Naso A, et al. Clinical effects of a low protein diet supplemented with essential amino acids and keto analogues in uremic patients. Contrib Nephrol 1986;53:137-43.

37 Gentile MG, Manna GM, Ferrario L, D'Amico G. Preliminary experience on dietary management of chronic renal failure. Contrib Nephrol 1986;53:102-8

38 Gretz N, Meisinger E, Strauch $M$. Influence of the underlying renal disease on the rate of progression. Contrib Nephrol 1986;53:92-101.

39 Lucas PA, Meadows JH, Roberts DE, Coles GA. The risks and benefits of a low protein-essential amino acid-keto acid diet. Kidney Int 1986;29: low protein

40 Rosman JB, Donker AJ, Meijer S, Sluiter WJ, Piers-Becht TP, Van Der Hem GK. Two years' experience with protein restriction in chronic renal failure. GK. Two years' experience with
Contrib Nephrol 1986;53:109-20.

41 Schmicker R, Frohling PT, Goetz KH, Kaschube I, Rakette I, Vetter K. Influence of low protein diet supplemented with amino acids and keto acids
on the progression of chronic renal failure. Contrib Nephrol 1986;53:121-7.

42 Gretz N, Meisinger E, Strauch M. Influence of diet and underlying renal disease on the rate of progression of chronic renal failure. Infusionstherapie und Klinische Ermahrung 1987;14 (suppl 5):21-5.

43 Jungers P, Chauveau P, Ployard F, Lebkiri B, Ciancioni C, Man NK. Comparison of ketoacids and low protein diet on advanced chronic renal failure progression. Kidney Int 1987;22:67-71.

44 Meisinger $E$, Strauch $M$. Controlled trial of two keto acid supplements on renal function, nutritional status, and bone metabolism in uremic patients. Kidney Int 1987;22:170-3.

45 Schmicker R, Vetter K, Lindenau K, Frohling PT, Kokot F. Conservative long-term treatment of chronic renal failure with keto acid and amino acid supplementation. Infusionstherapie 1987;14:34-8.

46 Walser M, Lafrance N, Ward L, Vanduyn MA. Progression of chronic renal failure in patients given keto acids following amino acids. Infusionstherapie und Klinische Ermahrung 1987;14(suppl 5):17-20.

47 Williams PS, Stevens ME, Fass G, Bone JM. A randomized trial of the effect of protein and phosphate restriction on the progression of chronic renal failure. Nephrol Dial Transplant 1987;7:285.

48 Barsotti G, Ciardella F, Morelli E, Cupisti A, Mantovanelli A, Giovannetti S. Nutritional treatment of renal failure in type 1 diabetic nephropathy. Cli Nephrol 1988;29:280-7.

49 Gentile MG, Fellin G, Manna GM, D'Amico G. Effects of dietetic manipulation on the control of blood pressure and on the progression of chronic renal insufficiency. Scand f Urol Nephrol Suppl 1988;108:13-5.

50 Frohling PT, Lindenau K, Vetter K, Krupki F, Schmicker R. What can be safely said about predialysis treatment? Blood Purif 1989;7:28-32.

51 Gretz N, Meisinger E, Strauch $M$. Does a low protein diet really slow down the rate of progression of chronic renal failure? Blood Purif 1989;7:33-8.

52 Ihle BU, Becker G, Whithworth JA, Charlwood RA, Kincaid-Smith PS. The effect of protein restriction on the progression of renal insufficiency. $N \mathrm{Engl}$ I Med 1989;321:1773-7.

53 Levine SE, D'Elia JA, Bistrian B, Smith-Ossman S, Gleason R, Mitch W, et al. Protein restricted diets in diabetic nephropathy. Nephron 1989;52:55-61.

54 Locatelli F, Alberti D, Graziani G, Buccianti G, Redaelli B, Giangrande A, et al. Prospective, randomised, multicentre trial of effect of protein restriction on progression of chronic renal insufficiency. Lancet 1991;337 1299-304.

55 Zeller K, Whittaker E, Sullivan L, Raskin P, Jacobson HR. Effect of 
restricting dietary protein on the progression of renal failure in patients with insulin-dependent diabetes mellitus. $N$ Engl $\tilde{J}$ Med 1991;324:78-84.

56 Lubowitz $\mathrm{H}$, Slatopolsky $\mathrm{F}$, Shankel $S$, Riesthach $\mathrm{RF}$, Bricker NS.

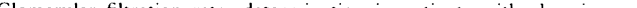
disease YAMA 1967;199:252-6.

$57 \mathrm{Klahr}$ S. The modification of diet in renal disease study. $N$ Engl f Med 1989;320:864-6.

58 Gretz N, Zeier M, Geberth S, Strauch M, Ritz E. Is gender a determinant for evolution of renal failure? A study in autosomal dominant polycystic kidney disease. Am F Kidney Dis 1989;14:178-83.
59 Cianciaruso B, Capuano A, D'Amaro E, Ferrera N, Nastasi A, Conte G, et al. Dietary compliance to a low protein and phosphate diet in patients with chronic renal failure. Kidney Int 1989;36 (suppl 27): S173-6.

60 Kopple JD), Berg R, Houser H, Steinman TI, Teschan P (MDRD Study Group). Nutritional status of patients with different levels of chronic renal insufficiency. Kidney Int 1989;36 (suppl 27): S184-94.

61 Maroni BJ, Steinman TI, Mitch WE. A method for estimating nitrogen intake of patients with chronic renal failure. Kidney Int 1985;27:58-65.

(Accepted 4 November 1991)

\title{
Mortality and occupational exposure to radiation: first analysis of the National Registry for Radiation Workers
}

\author{
G M Kendall, C R Muirhead, B H MacGibbon, J A O'Hagan, A J Conquest, A A Goodill, \\ B K Butland, T P Fell, D A Jackson, M A Webb, R G E Haylock, J M Thomas, T J Silk
}

Abstract
Objective-To study cause specific mortality of radiation workers with particular reference to associations between fatal neoplasms and level of exposure to radiation.

Design-Cohort study.

Setting-United Kingdom.

Subjects -95217 radiation workers at major sites of the nuclear industry.

Main outcome measure-Cause of death.

Results-Most standardised mortality ratios were below 100: 83 unlagged, 85 with a 10 year lag for all causes; 84 unlagged, 86 lagged for all cancers; and 80 for all known other causes, indicating a "healthy worker effect." The deficit of lung cancer (75 unlagged, 76 lagged) was significant at the $0 \cdot 1 \%$ level. Standardised mortality ratios were signifcantly raised (214 unlagged, 303 lagged) for thyroid cancer, but there was no evidence for any trend with external recorded radiation dose. Dose of external radiation and mortality from all cancers were weakly correlated $(p=0 \cdot 10)$, and multiple myeloma was more strongly correlated $(p=0.06)$; for leukaemia, excluding chronic lymphatic, the trend was significant $(p=0.03$; all tests one tailed). The central estimates of lifetime risk derived from these data were $10.0 \%$ per $\mathrm{Sv}(90 \%$ confidence interval $<0$ to $24 \%)$ for all cancers and $0.76 \%$ per $\mathrm{Sv}(0.07$ to $2.4 \%)$ for leukaemia (excluding chronic lymphatic leukaemia). These are, respectively, 2.5 times and 1.9 times the risk estimates recommended by the International Commission on Radiological Protection, but $\mathbf{9 0 \%}$ confidence intervals are large and the commission's risk factors fall well within the range. The positive trend with dose for all cancers, from which the risk estimate was derived, was not significant. The positive association between leukaemia (except chronic lymphatic leukaemia) was significant and robust in subsidiary analyses. This study showed no association between radiation exposure and prostatic cancer.

Conclusion - There is evidence for an association between radiation exposure and mortality from cancer, in particular leukaemia (excluding chronic lymphatic leukaemia) and multiple myeloma, although mortality from these diseases in the study population overall was below that in the general population. The central estimates of risk from this study lie above the most recent estimates of the International Commission on Radiological Protection for leukaemia (excluding chronic lymphatic leukaemia) and for all malignancies. However, the commission's risk estimates are well within the $90 \%$ confidence intervals from this study. Analysis of combined cohorts of radiation workers in the United
States indicated lower risk estimates than the commission recommends, and when the American data are combined with our analysis the overall risks are close to those estimated by the commission. This first analysis of the National Registry for Radiation Workers does not provide sufficient evidence to justify a revision in risk estimates for radiological protection purposes.

\section{Introduction}

Estimates of the risks of ionising radiation rest mainly on evidence from Japanese atomic bomb survivors and from people exposed for medical reasons. These groups provide information on risks from exposure to high doses at high dose rates. There is little direct evidence of the effects of lower doses and dose rates typical of occupational exposures. To provide such direct evidence the National Radiological Protection Board, after extensive consultation with the nuclear industry and other interested groups, set up the National Registry for Radiation Workers in 1976 as the national study of radiation workers, following individuals through different employments.

The first analysis of the registry covers over 95000 radiation workers whose collective dose from external radiation is about 3200 man Sv. The essentials of the study are described in this paper; more details can be found in a separate report.

\section{Methods}

Although the study population for the National Registry for Radiation Workers is broadly defined, practical considerations have limited the first analysis to certain groups. Radiation workers were divided into four categories: (a) those in radiation work when the registry was set up; $(b)$ those in employment at the inception of the study but no longer doing radiation work; (c) those who had left employment before the inception of the study; and $(d)$ those starting radiation work after the inception of the study.

It was recognised that it would be easier to ensure that data were complete and accurate for those still in radiation work, and at the request of the participating organisations those in categories $(a)$ and $(d)$ were generally the first to be enrolled. The first analysis of the registry includes the following groups of workers: from British Nuclear Fuels, category $(a)$ and $(d)$ workers from 1 January 1976, with category $(b)$ and $(c)$ for Sellafield and Chapelcross; from the Ministry of Defence Atomic Weapons Establishment, workers in all categories; from the Ministry of Defence, Defence Radiological Protection Service, workers in categories $(a)$ and $(d)$ from 1 January 1977; from Nuclear Electric, 